\title{
EFFECT OF SUPPLEMENTARY IRRIGATION AND \\ VARIETY ON YIELD AND SOME AGRONOMIC CHARACTERS OF SUNFLOWER GROWN UNDER RAINFED CONDITIONS IN NORTHERN SYRIA
}

Beg, A. ${ }^{1}$, Pourdad, S.S. ${ }^{2}$, Pala, M. ${ }^{3}$, and Oweis, T. $^{3}$

${ }^{1}$ Oilseed Program, ICARDA, Tehran, Iran

2 Oilseed Research Program and Agricultural Research Station, Sararood, Kermanshah, Iran

${ }^{3}$ Natural Resource Management Program, International Center for Agricultural Research in the Dry Areas (ICARDA), P.O. Box 5466, Aleppo, Syria

Received: September 14, 2006 Accepted: September 15, 2007

\section{SUMMARY}

Sunflower is an important edible oil crop. Its yield on dry lands of West Asia-North Africa is low due to limited rainfall at the time when this crop is in full growth during May-June, thus supplementary irrigation (SI) must be used. However, this region lacks river/canal water and irrigation, when possible, is from underground water storages, which, due to their quantitative scarcity, have to be used judiciously. This trial was conducted to assess the minimum SI application needed to produce optimum economic yields. The study was made for three years (1995-1997) at Tel Hadya, ICARDA, in northern Syria, on a soil characterized as fine clay (montmorillonitic, thermic Calcixerollic Xerochrept) with a $\mathrm{pH}$ around 8.0. We tested two open pollinated varieties, HO-1 and Record, and three water level treatments, rainfed, $50 \%$ of crop water requirement and $100 \%$ of crop water requirement. Effects of environment (years), variety and water level were observed on plant height, head and stem diameter, 200-seed weight, leaf area and sunflower grain yield. The results show that plant height, head diameter, stem diameter and leaf area differed significantly due to year effects while seed weight and yield differed non-significantly. The cultivars were significantly different only regarding seed weight and stem diameter. Grain yield obtained under rainfed conditions was highly significantly lower than those obtained under SI, with both lower and higher quantity of irrigation water. The average yield increase with $50 \%$ SI was $150 \%$ and with $100 \%$ SI was $312 \%$. However, the yield difference between the two irrigation levels was $66 \%$. This trial showed that $50 \%$ SI irrigation level can increase the yield substantially and economically, and can be resorted to in the absence of water for full irrigation.

Key words: West Asia-North Africa region, irrigation water scarcity, supplementary irrigation, sunflower yield 


\section{INTRODUCTION}

Sunflower (Helianthus annuus L.) is an important crop for edible oil production. It was grown at more than 20 million hectares in the world in 1997, including over one million hectares in West Asia-North Africa (WANA) countries. In WANA countries, there is a potential for substantial increase in sunflower acreage and production on dry land with optimum management practices, which can to some extent alleviate the edible oil deficiency in the region. In northern Syria, sunflower is usually planted in the spring season, from mid-February to mid-April. Like in most Mediterranean-type climates, sunflower flowering and grain filling take place during June and early July, under a high evapotranspirative demand when rains are absent. Consequently, the crop is often subjected to water deficit during grain formation, which results in low yields, between 1000 and $2000 \mathrm{~kg} / \mathrm{ha}$ (Fereres et al., 1986). Sunflower has a deep and extensive root system and it is often grown under rainfed conditions, but the crop is irrigated in areas where precipitation is limited. However, irrigation water is prioritized for the production of crops with greater economic returns. Sunflower responds positively to irrigation in both vegetative growth and seed yield in situation where the lack of water is negatively influencing normal plant development (Blamey, 1997).

In Syrian sunflower-growing areas, there is sufficient moisture in the soil at sowing time for the crop to germinate, emerge and grow up to flowering stage at about mid-April. However, to produce high yields, the crop must be irrigated several times from flowering till maturity using underground water from tube wells. Since underground water is limited in quantity and it cannot be replenished/ recharged by annual rains if excessively used, it is desirable to apply only that quantity of water that can increase the sunflower grain yield to an optimum, while overirrigation is avoided to conserve the underground water for other crops and future use.

Schneiter et al. (1988) reported that approximately 75 to $80 \%$ of the seasonal water has been used by the time the plants had reached the flower anthesis completion. The amount of water required by a sunflower crop in an area depends on rainfall, evaporative demand of the atmosphere, and water storage capacity of the soil (Unger, 1990). When water is limited, sunflower should be irrigated during early growth, to promote germination, seedling emergence, and adequate leaf expansion, and at anthesis, to prevent adverse effects of water deficit on seed yield. Patil and Gangavane (1990) found that subjecting sunflower to stress during the first 30 days of plant growth and development did not reduce seed yield. Tondreau et al. (1976) concluded that irrigation at anthesis and early maturity stages is important to obtain high seed yield. Unger (1990) reported that maximum dry matter accumulation in stems and leaves occurred 65 days after planting and maximum DM in head accumulated 75 days after planting in irrigation trials. Palmer (1981) reported that water stress as early as 20 days after planting reduced leaf number and leaf area. 
This research was undertaken to provide basic information on the performance of two open-pollinated sunflower varieties grown under rainfed conditions and supplementary irrigation. A specific objective was to determine the minimum supplementary irrigation need of sunflower to produce optimum economical yield.

\section{MATERIALS AND METHODS}

This study was conducted at Tel Hadya research station of ICARDA headquarters in Aleppo, Syria, on a soil defined as fine clay (montmorillonitic, thermic Calcixerollic Xerochrept) with a pH around 8.0. The area receives winter rain, as is usual with the Mediterranean climate, from end of October till May. The rainfall during the three years at the experimental site was $312.9 \mathrm{~mm}$ in 1994-95, 404.9 $\mathrm{mm}$ in 1995-96 and $433.7 \mathrm{~mm}$ in 1996-97. In 1994-95, the rainfall before the month of sowing was $202.6 \mathrm{~mm}, 16.5 \mathrm{~mm}$ in the month of sowing and $93.8 \mathrm{~mm}$ after sowing. In 1995-96, the respective rainfall values were $369.8 \mathrm{~mm}, 32.2 \mathrm{~mm}$ and $2.9 \mathrm{~mm}$. In that year almost all of the rain fell before sowing. In 1996-97, the respective rainfall values were $239.7 \mathrm{~mm}, 76.3 \mathrm{~mm}$ and $117.7 \mathrm{~mm}$. Precipitation and temperature data for the three years are given in Table 1.

Table 1: Growing-season monthly precipitation, temperature and long-term averages at Tel Hadya, Syria, 1994-1997

Precipitation in $\mathrm{mm}$

\begin{tabular}{lcccccccccccc}
\hline Year & Sept & Oct & Nov & Dec & Jan & Feb & Mar & Apr & May & June & Total & Average \\
\hline $1994-95$ & 1.3 & 15.7 & 98.1 & 45.1 & 42.4 & 16.5 & 24.5 & 48.3 & 19.5 & 1.5 & 312.9 & 31.29 \\
$1995-96$ & 00 & 10.3 & 68.3 & 35.5 & 73.7 & 45.0 & 137.0 & 32.2 & 2.9 & 00 & 404.9 & 40.5 \\
$1996-97$ & 22.9 & 35.3 & 17.4 & 92.5 & 46.8 & 24.8 & 76.3 & 111.7 & 6.0 & 00 & 433.7 & 43.4 \\
\hline Total & 24.2 & 61.3 & 183.8 & 173.1 & 162.9 & 86.3 & 237.8 & 192.2 & 28.4 & 1.5 & 1151.5 & 38.4 \\
Average & 8.1 & 20.4 & 61.3 & 57.7 & 54.3 & 28.8 & 79.3 & 64.1 & 9.5 & 0.5 & 383.8 & 38.4 \\
\hline Long-term & 0.5 & 24.8 & 50.0 & 52.2 & 62.8 & 57.3 & 39.3 & 25.6 & 16.5 & 2.7 & 332.4 & 33.2 \\
average & & & & & & & & & & & &
\end{tabular}

Mean maximum temperature, ${ }^{\circ} \mathrm{C}$

\begin{tabular}{|c|c|c|c|c|c|c|c|c|c|c|c|c|c|c|}
\hline Year & Sep & Oct & Nov & Dec & Jan & Feb & Mar & Apr & May & June & July & Aug & Total & Average \\
\hline 1994-95 & 37.3 & 30.3 & 17.8 & 9.6 & 12.2 & 16.5 & 18.9 & 23.1 & 31.6 & 35.7 & 35.9 & 37.3 & 306.2 & 25.5 \\
\hline $1995-96$ & 34.3 & 28.3 & 17.2 & 12.4 & 11.2 & 14.4 & 15.8 & 20.6 & 32.2 & 35.6 & 39.1 & 38.3 & 299.4 & 25.0 \\
\hline 1996-97 & 33.1 & 26.1 & 20.1 & 15.2 & 12.0 & 12.9 & 15.3 & 20.0 & 31.9 & 34.8 & 36.8 & 34.5 & 292.7 & 24.4 \\
\hline Average & 34.9 & 28.2 & 18.4 & 12.4 & 11.8 & 14.6 & 16.7 & 21.2 & 31.9 & 35.4 & 37.3 & 36.7 & 300.0 & 25.0 \\
\hline \multicolumn{15}{|c|}{ Mean minimum temperature, ${ }^{\circ} \mathrm{C}$} \\
\hline Year & Sep & Oct & Nov & Dec & Jan & Feb & Mar & Apr & May & June & July & Aug & Total & Average \\
\hline 1994-95 & 19.9 & 14.8 & 7.4 & 1.6 & 3.7 & 2.7 & 3.4 & 6.9 & 11.5 & 18.6 & 21.4 & 22.6 & 134.5 & 11.2 \\
\hline 1995-96 & 18.0 & 10.5 & 4.6 & 2.0 & 3.3 & 4.3 & 6.6 & 6.7 & 12.3 & 17.6 & 21.8 & 21.2 & 128.9 & 10.7 \\
\hline $1996-97$ & 17.1 & 11.0 & 7.1 & 7.3 & 2.6 & -1.0 & 2.2 & 6.3 & 11.6 & 17.7 & 21.4 & 21.4 & 124.7 & 10.4 \\
\hline Average & 18.3 & 12.1 & 6.4 & 3.6 & 3.2 & 2.0 & 4.1 & 6.6 & 11.8 & 17.9 & 21.5 & 21.7 & 129.4 & 10.8 \\
\hline
\end{tabular}


The average maximum temperature during the three years was $25^{\circ} \mathrm{C}$ with a range of 24.4 to $25.5^{\circ} \mathrm{C}$. The average minimum temperature was $10.8^{\circ} \mathrm{C}$ with a range of 10.4 to $11.2^{\circ} \mathrm{C}$.

Two open-pollinated sunflower varieties, HO-1 from USA and Record from Romania, were included in the trial. HO-1 is a high oil commercial variety in USA sunflower growing areas. It had been popular before introduction of hybrids. Record is a famous commercial variety from Romania. The sowing of trials was performed on 21 February in 1995, 4 April in 1996 and 2 March in 1997. In 1996, the sowing was delayed because of muddy soil in February/March. There were three water regimes - rainfed, SI-50\% and S1-100\% of the field water capacity. Experimental design was a randomized complete block in a split-split plot arrangement with years as the main plot, varieties as sub-plot and water regimes as sub-sub-plot. Treatments were replicated three times. Plot size was 1.2 by $12 \mathrm{~m}$, with three rows per plot $40 \mathrm{~cm}$ apart. Plant to plant distance was maintained at $15 \mathrm{~cm}$, sowing was done at higher seed rates and desired plant stand was obtained by thinning the stand when the crop was at 3-4 leaves stage. Seeding was done in furrows, which were covered with 5-6 cm of soil. Plots were hand weeded when necessary. All the plots were fertilized at planting with $50 \mathrm{~kg} / \mathrm{ha}$ of $\mathrm{P}_{2} \mathrm{O}_{5}$ and $40 \mathrm{~kg} / \mathrm{ha}$ of $\mathrm{N}$ as ammonium nitrate (33.5\%). The remaining $\mathrm{N}$ was side dressed at a rate of $60 \mathrm{~kg} \mathrm{~N} / \mathrm{ha}$ after thinning. The irrigation treatments were started before the crop reached the wilting point. In $1995,50 \%$ of supplementary irrigation amounted to $210 \mathrm{~mm}$ and $100 \%$ of SI was $419 \mathrm{~mm}$, applied in five irrigations. In 1996, the quantity of $50 \% \mathrm{SI}$ was $185 \mathrm{~mm}$ and 100\% SI was $373 \mathrm{~mm}$, applied in five irrigations. In 1997, 50\% SI was $182 \mathrm{~mm}$ and 100\% irrigation was $362 \mathrm{~mm}$, applied in four irrigations. Doses of SI were more or less similar each year, and they are presented together with the calculated evapotranspiration values for each variety in Table 2.

Table 2: Number of irrigations, irrigation dates and quantities of irrigation water applied in sunflower trials in 1995, 1996, and 1997 at Tel Hadya, ICARDA Syria

\begin{tabular}{|c|c|c|c|c|c|c|c|c|c|c|}
\hline $\begin{array}{l}\text { Year and } \\
\text { treatment }\end{array}$ & $\begin{array}{l}\text { Rain } \\
\mathrm{mm}\end{array}$ & $\frac{1^{\text {st }} / \mathrm{rr} .}{\mathrm{mm}}$ & $\frac{2^{\text {nd }} I r r .}{m m}$ & $\begin{array}{c}\frac{3^{\text {rd }} \mathrm{Irr} .}{\mathrm{mm}} \\
\end{array}$ & $\frac{4^{\text {th }} / \mathrm{rr} .}{\mathrm{mm}}$ & $\frac{5^{\text {th }} / \mathrm{rr} .}{\mathrm{mm}}$ & $\begin{array}{c}\text { Total irr. } \\
\mathrm{mm}\end{array}$ & $\begin{array}{c}\text { Rain+irr. } \\
\mathrm{mm}\end{array}$ & \multicolumn{2}{|c|}{$\frac{\text { Crop ET* }^{*}}{\mathrm{~mm}}$} \\
\hline 1995 & 312.9 & 9.4 .95 & 1.5 .95 & 24.5 .95 & 29.5.95 & 14.6 .95 & & & $\mathrm{HO}-1$ & Recd \\
\hline Rainfed & & - & - & & - & - & - & 312.9 & 199 & 226 \\
\hline SI 50\% & & 27 & 23 & 44 & 42 & 74 & 210 & 522.9 & 577 & 552 \\
\hline SI 100\% & & 53 & 47 & 88 & 83 & 148 & 419 & 731.9 & 864 & 853 \\
\hline 1996 & 404.9 & 14.5 .96 & 27.5 .96 & 6.6 .96 & 18.6 .96 & 2.7 .96 & & & & \\
\hline Rainfed & & - & - & & - & - & - & 404.9 & 365 & 356 \\
\hline SI 50\% & & 33 & 33 & 33 & 50 & 36 & 185 & 589.9 & 657 & 686 \\
\hline SI 100\% & & 67 & 67 & 67 & 100 & 72 & 373 & 777.9 & 880 & 893 \\
\hline 1997 & 433.7 & 16.5.97 & 5.6 .97 & 23.6.97 & 4.7 .97 & & & & & \\
\hline Rainfed & & - & - & & - & - & - & 433.7 & 351 & 356 \\
\hline SI 50\% & & 27 & 53 & 56 & 46 & - & 182 & 615.7 & 606 & 623 \\
\hline SI $100 \%$ & & 53 & 106 & 111 & 92 & - & 362 & 795.7 & 886 & 892 \\
\hline
\end{tabular}

* Evapotranspiration measured with neutron probe water measurement device. 
Drip irrigation method was applied. Soil water measurements were made with a neutron probe device in a single replication only, thus water use efficiency values were not subjected to statistical analysis.

Data were recorded for several variables such as plant height in $\mathrm{cm}$ at maturity, seed yield in grams from an area of $14 \mathrm{~m}^{2}, 200$-seed weight in grams, stem diameter in $\mathrm{mm}$, head diameter at maturity, and flowering date when $50 \%$ of flowers were open. The crop was harvested between 18 and 25 July. The data were analyzed by MSTAT-C statistical analysis system.

\section{RESULTS AND DISCUSSION}

Effects of years, varieties and water levels on yield and other growth factors are given in Table 3. The analyses of variance (Tables 5 and 6) showed that during three years of study there were significant differences for several variables due to effects of year, variety and water level. Differences due to water level are highly significant for all six variables.

Table 3: Effects of years, varieties and water level on yield and other growth factors of sunflower in three years, 1995, 1996 and 1997, at Tel Hadya, ICARDA, Syria

\begin{tabular}{|c|c|c|c|c|c|c|c|c|c|c|c|c|}
\hline \multirow[b]{2}{*}{ Variety } & \multicolumn{4}{|c|}{1995} & \multicolumn{4}{|c|}{1996} & \multicolumn{4}{|c|}{1997} \\
\hline & $\begin{array}{l}\text { Rain- } \\
\text { fed }\end{array}$ & $\begin{array}{c}\text { S.I } \\
50 \%\end{array}$ & $\begin{array}{c}\text { S.I } \\
100 \%\end{array}$ & $\begin{array}{l}\text { Aver- } \\
\text { age }\end{array}$ & $\begin{array}{l}\text { Rain- } \\
\text { fed }\end{array}$ & $\begin{array}{c}\text { S.I } \\
50 \%\end{array}$ & $\begin{array}{c}\text { S.I } \\
100 \%\end{array}$ & $\begin{array}{l}\text { Aver- } \\
\text { age }\end{array}$ & $\begin{array}{l}\text { Rain- } \\
\text { fed }\end{array}$ & $\begin{array}{c}\text { SI } 50 \\
\%\end{array}$ & $\begin{array}{c}\text { SI100 } \\
\%\end{array}$ & $\begin{array}{l}\text { Aver- } \\
\text { age }\end{array}$ \\
\hline \multicolumn{13}{|c|}{ Plant height (cm) } \\
\hline $\mathrm{HO}-1$ & 88.6 & 126.6 & 148.3 & 121.1 & 126.6 & 150.0 & 171.6 & 149.4 & 115.6 & 123.3 & 152.3 & 130.4 \\
\hline Record & 86.6 & 145.0 & 158.3 & 130.0 & 120.0 & 151.6 & 176.6 & 149.4 & 118.7 & 133.7 & 150.3 & 134.2 \\
\hline Average & 87.4 & 135.8 & 153.3 & 125.5 & 123.3 & 150.8 & 174.1 & 149.4 & 117.1 & 128.5 & 151.3 & 132.3 \\
\hline \multicolumn{13}{|c|}{ Head diameter $(\mathbf{c m})$} \\
\hline $\mathrm{HO}-1$ & 8.0 & 13.0 & 18.0 & 13.0 & 8.7 & 9.7 & 9.0 & 9.1 & 9.3 & 10.3 & 12.7 & 10.7 \\
\hline Record & 9.7 & 13.7 & 15.7 & 13.0 & 8.3 & 9.0 & 9.3 & 8.8 & 8.3 & 11.3 & 10.3 & 9.9 \\
\hline Average & 8.8 & 13.3 & 16.8 & 13.0 & 8.5 & 9.3 & 9.1 & 8.9 & 8.8 & 10.8 & 11.5 & 10.3 \\
\hline \multicolumn{13}{|c|}{ 200-seed-weight (g) } \\
\hline $\mathrm{HO}-1$ & 5.7 & 8.6 & 8.2 & 7.3 & 6.6 & 8.3 & 11.3 & 8.7 & 6.6 & 8.3 & 11.3 & 8.7 \\
\hline Record & 8.4 & 9.8 & 10.9 & 9.7 & 7.4 & 9.2 & 11.5 & 9.4 & 7.4 & 9.2 & 11.5 & 9.4 \\
\hline Average & 6.7 & 9.2 & 9.5 & 8.5 & 7.0 & 8.7 & 11.4 & 9.0 & 7.0 & 8.0 & 11.4 & 7.0 \\
\hline \multicolumn{13}{|c|}{ Stem diameter $(\mathrm{mm})$} \\
\hline $\mathrm{HO}-1$ & 11.3 & 17.7 & 21.0 & 16.6 & 15.3 & 20.0 & 19.7 & 18.3 & 21.3 & 26.3 & 29.3 & 18.9 \\
\hline Record & 11.7 & 17.0 & 22.0 & 16.9 & 14.3 & 18.3 & 18.7 & 17.1 & 21.3 & 18.3 & 25.0 & 21.5 \\
\hline Average & 11.5 & 17.3 & 21.5 & 16.7 & 14.8 & 19.1 & 19.2 & 17.7 & 21.3 & 22.3 & 27.1 & 23.5 \\
\hline \multicolumn{13}{|c|}{ Leaf area $\left(\mathrm{cm}^{2}\right)$} \\
\hline $\mathrm{HO}-1$ & 988 & 3830 & 7676 & 4165 & 2530 & 4067 & 5188 & 3928 & 4016 & 6124 & 11195 & 7111.6 \\
\hline Record & 1177 & 3976 & 7835 & 4329 & 2958 & 4208 & 4673 & 3946 & 4317 & 6976 & 9660 & 6984.3 \\
\hline Average & 1082 & 3903 & 7755 & 4247 & 2744 & 4137 & 4930 & 3937 & 4166 & 6550 & & \\
\hline \multicolumn{13}{|c|}{ Grain yield (kg/ha) } \\
\hline $\mathrm{HO}-1$ & 213 & 995 & 1643 & 950 & 417 & 1166 & 1448 & 1010 & 450 & 945 & & \\
\hline Record & 257 & 973 & 1972 & 1067 & 517 & 772 & 1063 & 784 & 554 & 1119 & & \\
\hline Average & 235 & 984 & 1807 & 1008.5 & 467 & 969 & 1255 & 897 & 502 & 1032 & & \\
\hline
\end{tabular}




\section{$50 \%$ flowering}

There were slight differences in flowering between the varieties. HO-1 flowered (50\%) about four days earlier than Record each year. Rainfed crop flowered 1-2 days earlier than irrigated crop. In 1995, HO-1 took 105 days to flower. This period was longer than those in the two subsequent years, which was due to early planting in the first year. In 1996, it took 86 days to flower, the main reason being late planting, on 4 April. In the final year, 50\% flower was reached in 97 days. Number of days to flower shows that the required growing degree days for sunflower $50 \%$ flowering is reached by 7 June for HO-1 and by 13 June for Record in Tel Hadya climate.

The mean values for PH, HD, TSW, SD, LA and yields are given in Tables 4a, 4b and $4 \mathrm{c}$. Values of variation coefficients and statistical comparisons are given in Tables 5-6.

\section{Plant height (PH)}

There were significant differences in PH due to year effect. The first year with lower rainfall produced low plant height $(125.5 \mathrm{~cm})$, while the two subsequent years receiving higher and about equal moisture had similar PH of 149.4 and 132.3 $\mathrm{cm}$. The average PH of the varieties was similar statistically. There were highly significant differences in PH due to water level. The interaction year $\times$ water level was also highly significant. The coefficient of variation (CV) for PH was $7.52 \%$.

\section{Head diameter (HD)}

It followed the same trend as $\mathrm{PH}$ for year, variety and water level. However, HD was unexpectedly higher $(13.0 \mathrm{~cm})$ for rainfed crop in the first year. HD for the two subsequent years was similar $(9.0$ and $10.4 \mathrm{~cm})$. Early planting in the first year compared with the two subsequent years can be a reason for larger HD in 1995. HD of the varieties was similar (10.9 and $10.6 \mathrm{~cm}$ ). The differences due to water level and its interaction with years were highly significant. The rainfed sunflower had smaller HD of $7.0 \mathrm{~cm}$, while SI had higher HD of 9.1 and $10.8 \mathrm{~cm}$ obviously due to higher quantities of moisture. CV for HD was $16.48 \%$.

\section{0-seed weight (TSW)}

It was similar in all years, being $8.5,9.3$ and $9.0 \mathrm{~g}$. There was a significant difference between TSW of the varieties, $8.15 \mathrm{~g}$ for HO-1 and $9.6 \mathrm{~g}$ for Record at $2 \%$ probability. There were highly significant TSW differences due to water level, as expected. The rainfed variant had the lowest seed weight of $7.0 \mathrm{~g}$, SI $50 \%$ had $9.1 \mathrm{~g}$ and $100 \%$ SI had $10.8 \mathrm{~g}$. CV for TSW was $18.11 \%$.

\section{Stem diameter (SD)}

It was significantly different due to the year of growing. SD for the first year was $16.8 \mathrm{~mm}$ which was higher than SD for the second year $(11.7 \mathrm{~mm})$. This may be 
due to a very late planting. HO-1 had greater SD (20.2 mm) compared with Record ( $18.5 \mathrm{~mm})$. SD had consistently increased with water level. Year $\times$ water level interaction was also significant for this variable. CV for SD was $18.11 \%$.

\section{Leaf area (LA)}

There were significant differences due to the year of growing. Similar values were obtained in the first two years and a much greater value in the last year, in line with the highest quantity of moisture available in the last year. LA has significantly increased due to water level, the lowest being in the first year and significantly increasing in the two subsequent years. The interactions were non-significant. CV for LA was highest (39.4\%) among the variables. The interactions WL $\times \mathrm{C}$ and $\mathrm{Y} \times$ $\mathrm{WL} \times \mathrm{C}$ were non-significant for all six variables.

Table 4: Average differences in sunflower variables due to year, variety and water level at Tel Hadya, ICARDA, Syria

a) Average differences in variables due to year effects

\begin{tabular}{lcccc}
\hline Variable & 1995 & 1996 & 1997 & SE of mean \\
\hline Plant height $(\mathrm{cm})$ & 125.5 & 149.4 & 132.3 & \\
Head diameter $(\mathrm{cm})$ & 13.0 & 9.0 & 10.4 & \\
200-seed weight $(\mathrm{g})$ & 8.5 & 9.3 & 9.0 & \\
Stem diameter $(\mathrm{mm})$ & 16.8 & 11.7 & 23.6 & \\
Leaf area $\left(\mathrm{cm}^{2}\right)$ & 4247 & 3937 & 7048 & \\
Seed yield $(\mathrm{kg} / \mathrm{ha})$ & 1009 & 897 & 1143 & \\
\hline
\end{tabular}

b) Average differences in variables due to effects of variety

\begin{tabular}{lccc}
\hline Variable & HO-1 & Record & SE of mean \\
\hline Plant height $(\mathrm{cm})$ & 133.7 & 137.8 & \\
Head diameter $(\mathrm{cm})$ & 10.9 & 10.6 & \\
200-seed weight $(\mathrm{g})$ & 8.3 & 9.6 & \\
Stem diameter $(\mathrm{mm})$ & 20.2 & 18.5 & \\
Leaf area $\left(\mathrm{cm}^{2}\right)$ & 5068 & 5087 \\
Seed yield $(\mathrm{kg} / \mathrm{ha})$ & 1037 & 996 & \\
\hline
\end{tabular}

c) Average differences in variables due to effects of water levels

\begin{tabular}{lcccc}
\hline Variable & Rainfed & $50 \%$ SI & $100 \%$ SI & SE of Mean \\
\hline Plant height $(\mathrm{cm})$ & 109.3 & 138.4 & 159.6 & \\
Head diameter $(\mathrm{cm})$ & 8.7 & 11.2 & 12.5 & \\
200-seed weight $(\mathrm{g})$ & 7.0 & 9.1 & 10.8 & \\
Stem diameter $(\mathrm{mm})$ & 15.8 & 19.6 & 22.6 & \\
Leaf area $\left(\mathrm{cm}^{2}\right)$ & 2664.4 & 4863.5 & 7704 \\
Seed yield $(\mathrm{kg} / \mathrm{ha})$ & 401 & 995 & 1652 & \\
\hline
\end{tabular}


Table 5: Summary of the analyses of variance for seed yield and other agronomic variables for two sunflower varieties, three growing seasons $(1995,1996,1997)$ at Tel Hadya, Syria, and three different water levels (rainfed, 50\% and 100\% supplementary irrigation)

\begin{tabular}{|c|c|c|c|c|c|c|c|}
\hline Source of variation & Df & $\begin{array}{l}\text { Seed } \\
\text { yield }\end{array}$ & $\begin{array}{c}\text { 200-seed } \\
\text { weight }\end{array}$ & $\begin{array}{c}\text { Head } \\
\text { diameter }\end{array}$ & $\begin{array}{c}\text { Plant } \\
\text { height }\end{array}$ & $\begin{array}{c}\text { Stem } \\
\text { diameter }\end{array}$ & $\begin{array}{l}\text { Leaf } \\
\text { area }\end{array}$ \\
\hline Year $(Y)$ & 2 & 271945.8 & 2.899 & 74.24 & 2728.2 & 246.8 & 52846173 \\
\hline Cultivar (C) & 1 & 22488.9 & 25.765 & 1.5 & 240.6 & 39.2 & 4501 \\
\hline $\mathrm{Y} \times \mathrm{C}$ & 2 & 134883.5 & 4.003 & 0.722 & 89.5 & 21.9 & 95996 \\
\hline Water level (WL) & 2 & 7047249.1 & 65.389 & 66.1 & 11467.4 & 204.1 & 114925232 \\
\hline$Y \times W L$ & 4 & 290213.2 & 2.195 & 21.6 & 605.4 & 21.6 & 9830448 \\
\hline$C \times W L$ & 2 & 53513.5 & 0.534 & 4.2 & 159.1 & 11.9 & 1426361 \\
\hline $\mathrm{Y} \times \mathrm{C} \times \mathrm{WL}$ & 4 & 112324.9 & 0.812 & 3.4 & 208.4 & 6.7 & 633478 \\
\hline Error for WL & 24 & 91036.5 & 2.624 & 3.2 & 104.2 & 4.9 & 3924010 \\
\hline Coefficient of variatic & & $27 \%$ & $18 \%$ & $16 \%$ & $7.5 \%$ & $11 \%$ & $39.01 \%$ \\
\hline
\end{tabular}

Table 6: Summary of the analyses of variance of several variables for two sunflower cultivars grown in three years $(1995,1996,1997)$ at three water levels (rainfed, 50\% and $100 \%$ supplementary irrigation)

\begin{tabular}{|c|c|c|c|c|c|c|c|}
\hline Source of variation & $\begin{array}{l}\text { Degrees of } \\
\text { freedom }\end{array}$ & $\begin{array}{l}\text { Plant } \\
\text { height }\end{array}$ & $\begin{array}{c}\text { Head } \\
\text { diameter }\end{array}$ & $\begin{array}{c}\text { 200-seed } \\
\text { weight }\end{array}$ & $\begin{array}{c}\text { Stem } \\
\text { diameter }\end{array}$ & $\begin{array}{l}\text { Leaf } \\
\text { area }\end{array}$ & $\begin{array}{l}\text { Yield } \\
\mathrm{kg} / \mathrm{ha}\end{array}$ \\
\hline Year $(\mathrm{Y})$ & 2 & ** & ** & NS & ** & * & NS \\
\hline Cultivar @ & 1 & NS & NS & $\star \star$ & * & NS & NS \\
\hline$Y \times C$ & 2 & NS & NS & NS & NS & NS & NS \\
\hline Water level (WL) & 2 & $\star \star$ & ** & $\star \star$ & $\star \star$ & ** & $\star \star$ \\
\hline$Y \times W L$ & 4 & ** & $\star \star$ & NS & $\star \star$ & NS & * \\
\hline $\mathrm{WL} \times \mathrm{C}$ & 2 & NS & N.S & NS & NS & NS & NS \\
\hline$Y \times C \times W L$ & 4 & NS & N.S & NS & NS & NS & NS \\
\hline
\end{tabular}

* Significant at $5 \%$ probability, ${ }^{\star *}$ significant at $1 \%$ probability, NS nonsignificant

\section{Sunflower grain yield}

There were no significant differences in average yield due to the year of growing. The yield was $1009 \mathrm{~kg} /$ ha for the first year, $897 \mathrm{~kg} / \mathrm{ha}$ for the second year and 1143 $\mathrm{kg} / \mathrm{ha}$ for the third year. The two varieties produced similar yields, HO-1 producing $1035 \mathrm{~kg} / \mathrm{ha}$ and Record $955 \mathrm{~kg} / \mathrm{ha}$. There were highly significant differences in yield due to water level. The average rainfed yield was $401 \mathrm{~kg} / \mathrm{ha}$. The yield was more than double (995 kg/ha) with 50\% SI and more than four times higher with $100 \%$ SI ( $1652 \mathrm{~kg} / \mathrm{ha}$ ). The increase in yield by $50 \%$ SI over rainfed was $148 \%$ and by $100 \%$ SI was $312 \%$. However, the difference between the yields of $50 \%$ SI and $100 \%$ SI was $657 \mathrm{~kg}$, which is $66 \%$ in favor of the latter. Grain yield of sunflower was highly significantly increased due to the application of supplementary irrigation, both the lower and the higher quantity of water. However, the initial increase due to $50 \%$ SI was much above that of $100 \%$ SI. Since yield is the main factor of economic importance, it needs further analysis to arrive at the economic quantity of irrigation 
needed for optimum economic grain yield. The increases in sunflower grain yield due to irrigation over rainfed crop are given in Table 7 , which also shows the yield of varieties in each year at each water level.

Table 7: Yield performance of sunflower due to water level (rain moisture and application of two levels of supplementary irrigation) at Tel Hadya, ICARDA, Syria, in 1995, 1996 and 1997 (yield in $\mathrm{kg} / \mathrm{ha}$ )

\begin{tabular}{llccc}
\hline Year & Variety & Rainfed & $50 \%$ SI & $100 \%$ SI \\
\hline \multirow{4}{*}{1995} & HO-1 & 213 & 995 & 1643 \\
& Yield increase (\%) & - & 367 & 671 \\
& Record & 257 & 973 & 1972 \\
& Yield increase (\%) & - & 278 & 667 \\
\hline \multirow{4}{*}{1996} & HO-1 & 417 & 1166 & 1448 \\
& Yield increase (\%) & - & 182 & 247 \\
& Record & 517 & 772 & 1063 \\
& Yield increase (\%) & - & 49 & 1065 \\
\hline \multirow{4}{*}{1997} & HO-1 & 450 & 945 & 2050 \\
& Yield increase (\%) & - & 110 & 356 \\
& Record & 554 & 1119 & 1735 \\
& Yield increase (\%) & - & 102 & 213 \\
\hline \multirow{4}{*}{$3-Y r$ Avg. } & HO-1 & 360 & 1035 & 1714 \\
& Yield increase (\%) & - & 188 & 376 \\
& Record & 443 & 955 & 1590 \\
& Yield increase (\%) & - & 116 & 259 \\
& Variety mean & 401 & 995 & 1652 \\
& Yield increase (\%) & - & 148 & 312 \\
\hline
\end{tabular}

In the first year, the yield of the variety HO- 1 increased by $367 \%$ and $671 \%$ with the application of $50 \%$ and $100 \%$ SI, respectively. In Record, the yield increased by $278 \%$ with $50 \%$ SI and by $667 \%$ with $100 \%$ SI, similarly to HO- 1 . The trend remained the same for the two subsequent years. It is of interest to note that $50 \% \mathrm{SI}$ was more effective for the variety HO-1. The three-year average yield of the variety HO- 1 increased by $188 \%$ while that of the variety Record increased by $116 \%$. Similarly, with $100 \%$ SI, the yield of HO-1 increased by $376 \%$ while that of Record by $259 \%$. This study showed that varieties are available which have enhanced response to limited SI and are suitable for rained areas. A large collection of varieties needs to be screened for selection of these traits. Thus there is a strong case for determining actual quantities of irrigation needed to produce optimum yield without waste of scarce underground fossil water, the replenishment of which by annual rainfall is not adequate, thus SI needs to be used judiciously by determining its quantity in conjunction with the rainfall in the given location. 


\section{Water use efficiency (WUE)}

WUE was estimated for mean grain yields for the different years and varieties on the basis of crop evapotranspiration values as given in Table 8. WUE was obtained by dividing the average yield of the varieties (Table 7) in each year at different water levels with evapotranspiration values (Table 2). The figures obtained show that WUE was higher with increased amounts of SI for both varieties and in all years except 1996. However, water use by sunflower crop in general is quite high, so that its water use efficiency values are low when compared with the cereals because of its large vegetative growth and large leaves. The varieties did not show any trend over each other for better WUE under similar conditions of water supply. In summary, the sunflower is not a water efficient crop and it should be grown more in rainfed fields with high seasonal rainfall. Sunflower growing is recommended only if there is a need for vegetable oil. However, socio-economic benefits should be considered for crop choices under the existing farming conditions.

Table 8: Mean grain water use efficiency $(\mathrm{kg} / \mathrm{ha} / \mathrm{mm})$ of sunflower varieties in different years and water levels

\begin{tabular}{lcccccc}
\hline \multirow{2}{*}{ Variety } & \multicolumn{2}{c}{1995} & \multicolumn{2}{c}{1996} & \multicolumn{2}{c}{1997} \\
\cline { 2 - 7 } & HO-1 & Record & HO-1 & Record & HO-1 & Record \\
\hline Rainfed & 1.07 & 1.14 & 1.14 & 1.45 & 1.28 & 1.56 \\
$50 \% \mathrm{SI}$ & 1.72 & 1.76 & 1.77 & 1.13 & 1.56 & 1.80 \\
$100 \% \mathrm{SI}$ & 1.90 & 2.31 & 1.64 & 1.19 & 2.31 & 1.94 \\
Average & 1.56 & 1.74 & 1.52 & 1.26 & 1.72 & 1.77 \\
\hline General Average & \multicolumn{3}{c}{1.65} & \multicolumn{3}{c}{1.39} \\
\hline
\end{tabular}

Note: Water measurements were made in a single replication so there is no statistical analysis applied for WUE.

\section{CONCLUSION}

Judicious use of supplementary irrigation for spring-sown sunflower crop generally increases its yield from 150 to more than $300 \%$. Such increases are due to the fact that sunflower crop needs moisture from flowering to the end of grain filling, the period (June - August) in which the rainfall is not forthcoming in the Mediterranean region.

\section{REFERENCES}

Blamey, F.P.C., Zollinger, R.K., Schneiter, A.A., 1997. Sunflower Production and Culture. In: A.A. Schneiter (ed.) Sunflower Technology and Production. ASA, CSSA, and SSSA, Madison WI, pp. 595-670.

Fereres, E., Gimenez, C., and Fernandez, J.M., 1986. Genetic variability in sunflower cultivars under drought. 1. Yield relationships. Aust. J. Agric. Res. 37: 573-582.

Patil, B.P., and Gangavane, S.B., 1990. Effects of water stress imposed at various growth stages on yield of groundnut and sunflower. J. Maharashtra Agric. Univ. 15(3): 322-324. 
Schneiter, A.A., Cukarar, T.J.B., Zarraroni, E.E. and Majid, H., 1988. Agronomic evaluation of semidwarf sunflower. In Proc. $12^{\text {th }}$ Int. Sunflower Conference. Novi Sad Yugoslavia. 25-29 July. Int. Assoc. Paris France, pp. 363-368.

Tondreau, A., Tosso, T.J. and Moroni, V.J., 1976. Irrigation frequency in sunflower (Helianthus annuus L.) based on critical growth. Agric. Tecnica 34(4): 156-159.

Unger, P.W., 1990. Sunflower. In: B.A. Stewart and D.R. Nielson (ed). Irrigation of Agricultural Crops. ASA, CSSA, and SSSA., Madison WI, pp. 775-794.

Marc, J., and Palmer, J.H., 1981. Photoperiodic sensitivity of inflorescence initiation and development in sunflower. Field Crops Res. 4: 155-164.

\title{
INFLUENCIA DE LA IRRIGACIÓN COMPLEMENTARIA Y LA VARIEDAD EN EL RENDIMIENTO Y ALGUNAS CARACTERÍSTICAS AGRONÓMICAS DE GIRASOL CULTIVADO EN LAS CONDICIONES DE LA LABRANZA SECA EN SIRIA DEL NORTE
}

\author{
RESUMEN
}

\begin{abstract}
El girasol es un cultivo oleaginoso importante. Su rendimiento en los suelos secos de Asia occidental y de África septentrional es bajo, debido a las limitadas precipitaciones en la temporada cuando la plantación se encuentra en pleno crecimiento, durante mayo y junio. Por ello debe utilizarse la irrigación complementaria (SI). Pero, a esta región le falta agua de ríos o canales, pues la irrigación, cuando resulta posible, se efectúa de los tanques subterráneos que, debido a sus limitadas capacidades, deben utilizarse con cuidado. Esta investigación ha sido emprendida con el fin de determinar la cantidad mínima de irrigación complementaria, necesaria para el logro de ptimos rendimientos económicos. Las investigaciones fueron llevadas a cabo a lo largo de un período de tres años (1995-1997) en Tel Hadya, ICARDA, Siria del Norte, en el suelo caracterizado como arcilla fina (montmorilonítica, xerocrept calcixerólico cálido) con el valor de $\mathrm{pH}$ de alrededor de 8.0. Se investigaron dos variedades de fecundación cruzada, HO-1 y Record, y tres niveles de adición de agua, labranza seca, 50\% de la necesidad de las plantaciones y $100 \%$ de la necesidad de las plantaciones. Se observaban la influencia del entorno (años), de las variedades y del nivel de irrigación en la altura de la planta, diámetro del tallo, peso de 200 granos, la superficie de la hoja y el rendimiento de la semilla de girasol. Los resultados demuestran que la altura de la planta, el diámetro del capítulo, el diámetro del tallo y la superficie de la hoja, varían significativamente por causa de la influencia del año, mientras que el peso del grano y el rendimiento, varían debajo del límite de significación. Las variedades diferían significativamente sólo en cuanto al peso del grano y el diámetro del tallo. El rendimiento de la semilla obtenido en la labranza seca, fue significativamente más bajo de los rendimientos obtenidos en los variantes de irrigación complementaria, con la menor dosis del agua, tanto como con la mayor dosis del agua de irrigación. El incremento promedio de rendimiento en la variante $50 \%$ SI fue $150 \%$, y en la variante $100 \%$ SI fue $312 \%$. Pero, la diferencia en los rendimientos entre dos variantes irrigadas, fue $66 \%$. Esta investigación ha demostrado que la variante de la irrigación complementaria de 50\% SI puede incrementar el rendimiento significativa y económicamente, y que esta solución puede aplicarse en las condiciones de carencia de agua para una plena irrigación.
\end{abstract}




\title{
IRRIGATION ADDITIONNELLE ET VARIÉTÉ: EFFET SUR LE RENDEMENT ET SUR CERTAINES CARACTÉRISTIQUES DU TOURNESOL CULTIVÉ DANS DES ZONES ALIMENTÉES PAR LES EAUX PLUVIALES EN SYRIE DU NORD
}

\author{
RÉSUMÉ
}

Le tournesol est une importante culture oléagineuse. Dans les sols arides de l'ouest de l'Asie et du nord de l'Afrique son rendement est faible à cause du nombre réduit des précipitations en mai et en juin au moment où cette culture est en pleine croissance et il faut donc avoir recours à une irrigation additionnelle (IA). Cependant, dans cette région la quantité d'eau tirée de canaux ou de rivières est insuffisante et l'irrigation, quand elle est possible, provient de réservoirs souterrains de faible contenance qui doivent être utilisés judicieusement. Cette expérience a été faite dans le but de déterminer la quantité minimale d'eau provenant d'irrigation additionnelle qui puisse produire des rendements économiques maximaux. L'étude a été menée sur une durée de trois ans (1995-1997) à Tel Hadya, ICARDA, en Syrie du Nord sur un sol caractérisé comme sol d'argile fine (montmorillonitique, Xerochrept Calcixerollic thermique) ayant un pH d'environ 8.0. Deux variétés de pollinisation libre, HO1 et Record, ainsi que trois niveaux d'addition d'eau, zones alimentées par les eaux pluviales, $50 \%$ des besoins de la culture et $100 \%$ des besoins de la culture ont été étudiées. Les effets de l'environnement (années), de la variété et du niveau d'irrigation sur la hauteur de la plante, le diamètre de la tête et celui de la tige, le poids de 200 graines, la surface de la feuille et le rendement en graines de tournesol ont été examinés. Les résultats montrent que la hauteur de la plante, le diamètre de la tête, celui de la tige et la surface de la feuille variaient de manièe importante sous l'influence de l'année tandis que le poids des graines et le rendement ne variaient pas de manière significative. Les cultivars variaient de manière importante seulement pour ce qui est du poids des graines et du diamètre de la tige. Le rendement en graines obtenu dans des sols alimentés par les eaux pluviales était beaucoup plus faible que les rendemnts obtenus dans les variétés irriguées de manière additionnelle, autant par des quantités faibles que par des quantités plus grandes d'eau. L'augmentation du rendement moyen avec $50 \%$ d'eau d'irigation était de $150 \%$ et avec $100 \%$, de $312 \%$. Cependant, la différence de rendement entre les deux niveaux d'irrigation était de $66 \%$. Cette expérience a démontré qu'un niveau de $50 \%$ d'irrigation additionnel pouvait augmenter le rendement de manière substantielle et économique et qu'on peut y avoir recours si l'eau est insufisante pour une irrigation complète. 